'llu. Revista de Ciencias de las Religiones

ISSN: $1135-4712$

http://dx.doi.org/10.5209/ILUR.57424

\title{
La tendencia universalista en el espejo de un icono «islamo-cristiano» de Tatáritsa, Bulgaria
}

\author{
Vladislava Spasova Ilieva ${ }^{1}$
}

Recibido: 14 de septiembre de 2016 / Aceptado: 13 de enero de 2017

Resumen. El espíritu supraconfesional, muy característico del mundo otomano, que tendía a reagrupar elementos muy diversos y que se basaba en la convicción universal según la cual todas las religiones se valoran y compiten por los mismos fines, todavía resuena en los Balcanes. Ejemplo significativo, que en este artículo se analiza desde la perspectiva del fenómeno de la santidad compartida ${ }^{2}$ y como espejo de muy diversas influencias, es un icono de Bulgaria, inusual representación «islamo-cristiana», de la Virgen con el Niño, que hace poco se encontraba en un pueblo, donde aparte de los «turcos» y los búlgaros, todavía habitan descendientes de los cosacos del Don, que son étnicamente rusos.

Palabras clave: La Virgen Odiguitria; cultos compartidos; sincretismo religioso; tártaros; Bulgaria.

\section{[en] The universalist tendency in the mirror of a «Islamic-Christian» icon of Tatáritsa, Bulgaria}

\begin{abstract}
The supraconfessional spirit, very characteristic of the Ottoman world, which tended to regroup many different elements, and was based on the universal conviction, according to which all religions are valued and competed for the same purposes, still resonates in the Balkans. A significant example, that in this article is analyzed from the perspective of the phenomenon of shared holiness and as a mirror of diverse influences, is an icon of Bulgaria, the unusual Islamic-Christian representation of the Virgin and Child, which was recently located in a village where, apart from the «Turks» and Bulgarians, there are still living descendants of the Don Cossacks, who are ethnically Russian.
\end{abstract}

Keywords: The Virgin Hodegetria; shared cults; religious syncretism; Tatars; Bulgaria.

Sumario. 1. Introducción. 2. El contexto confesional y étnico de Tatáritsa. 3. Hipótesis del modelo iconográfico que se había seguido y los «elementos extraños». 4. Influencias musulmanas; tártaros y cosacos. 5. ¿Santidad compartida o caso herético? 6. El gesto inaudito de Mariam. 7. Conclusiones. 8. Bibliografía.

Cómo citar: Spasova Ilieva, V., (2017), La tendencia universalista en el espejo de un icono «islamocristiano» de Tatáritsa, Bulgaria, en 'Tlu. Revista de Ciencias de las Religiones 22, 451-473.

$1 \quad$ Investigadora independiente.

E-mail: semiramissia@yahoo.com

2 Este fenómeno fue objeto principal de mi investigación para la obtención del grado de doctor, y dio el título de mi Tesis: La santidad compartida: la encrucijada del islam y la ortodoxia cristiana en los Balcanes, reflejos en Bulgaria, Spasova Ilieva 2015. 


\section{Introducción}

El icono sacro en la espiritualidad oriental es la imagen de lo invisible a través de la cual se hace visible la realidad sobrenatural, pues ésa es la fuerza o energía del icono, que es un objeto funcional ${ }^{3}$; incluye en sí la expresión y la contemplación. La plegaria encerrada y convertida en figura lleva un mensaje de elevación, que quiere tender un puente desde el mundo sensible al mundo espiritual.

El tema fundamental del icono-imagen es el hombre redimido, por tanto, su expresión y representación ha de ser equilibrada, armoniosa, ligera y luminosa, pues el icono no pretende mostrar el rostro cotidiano del hombre, sino su rostro glorioso y eterno, en el que se manifiesta la Xópıৎ divina (gracia, energía increada ${ }^{4}$ ), que a menudo viene expresada mediante el color dorado de los fondos. Este lenguaje de forma y color representa el modo de sentir, manifestar y vivir la fe de todo un mundo. Los colores que se usan comportan todo un abanico de significantes. Incluso la madera sobre la que se pinta, «porque justamente la madera fue sacralizada por la muerte de Jesús en la Cruz» ${ }^{5}$, tiene un sentido espiritual en el icono; «pulida la madera $[\ldots]$ se recubre de oro puro, símbolo de la luz divina» ${ }^{6}$.

Ambas ideas, lo humano y lo divino, lo terreno y lo celestial en el icono, se manifiestan a través del color. A través del color, en los iconos, paradójicamente, quedaron también «grabadas» las tendencias sincréticas y las ideas universalistas en el ámbito religioso del contexto balcánico que estamos estudiando.

En este sentido, quiero llamar la atención hacia una imagen cristiana (que según el canon sería considerada herética), muy peculiar y única en la iconografía, estampa espectacular del flujo de ideas en época de herejías y sincretismos, que representa la Virgen con el $\mathrm{Hijo}^{7}$, que fue hallada en una colección privada en Bulgaria (1999), y que pertenecía a una familia de la localidad de Tatáritsa ${ }^{8}$.

Antes de detenerme en los detalles de la imagen, que merecen una reflexión especial, es necesario aproximarse al contexto confesional y étnico del pueblo donde se encontró este icono, cuyo mismo nombre resulta por una parte paradójico, pero por otra, muy significativo en relación con el fenómeno que estamos estudiando. Y no por casualidad, se hallaba en el entorno en el que estaba y donde se veneraba, pues

Jrisoulas 2014.

4 El término Xápıs [Jaris] no es de uso habitual en el mundo católico occidental, pero es lo más adecuado cuan-

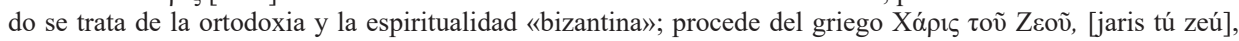

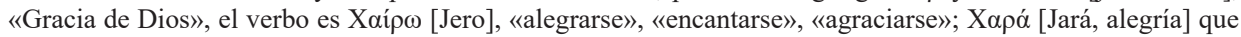
se energiza de la Xópıs es la palabra divina que empieza la nueva obra de Dios en el Nuevo Testamento. Especialmente en el campo de la redención, la Xápıৎ es en particular el don de Dios, que se derramó del sacrificio de la Cruz de Cristo, y funcionando dentro en la Iglesia, envuelve al hombre débil y pecador, lo santifica cuando co-

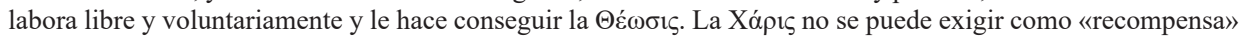
por obras buenas, pero se atrae especialmente con la $\tau \alpha \pi \varepsilon \iota v o \varphi \rho \circ \sigma u ́ v \eta$ (actitud sensata y humilde interior), por la $\mu \varepsilon \tau$ ćvora (introspección, arrepentimiento, conversión de la conducta del hombre) y el corazón quebrantado (cf.1P 5: 5). La divina Xópıৎ se da con los santos Misterios de la Iglesia, véase: Jrisoulas 2013.

Leconte 1984, 46.

Leconte $1984,46$.

Fig. 1.

8 En el pasado Tatáritsa fue un pueblo independiente, hoy día es uno de los tres grandes barrios del pueblo de Aydemir. Está situado a unos $5 \mathrm{~km}$ al oeste de la ciudad de Silístra (extremo noreste de Bulgaria) y a $3 \mathrm{~km}$ al sur del Danubio. Agradezco a Teodora Georgieva (que conoció el original y fue la primera que arrojó luz sobre la existencia de dicha imagen, Georgieva 2002, 61-65), por su disposición y esfuerzos, facilitándome una reproducción fotográfica de color de dicho icono, que me permitió completar esta investigación; véanse: Spasova Ilieva 2015, 934, fig. $n^{\circ} 79$. 


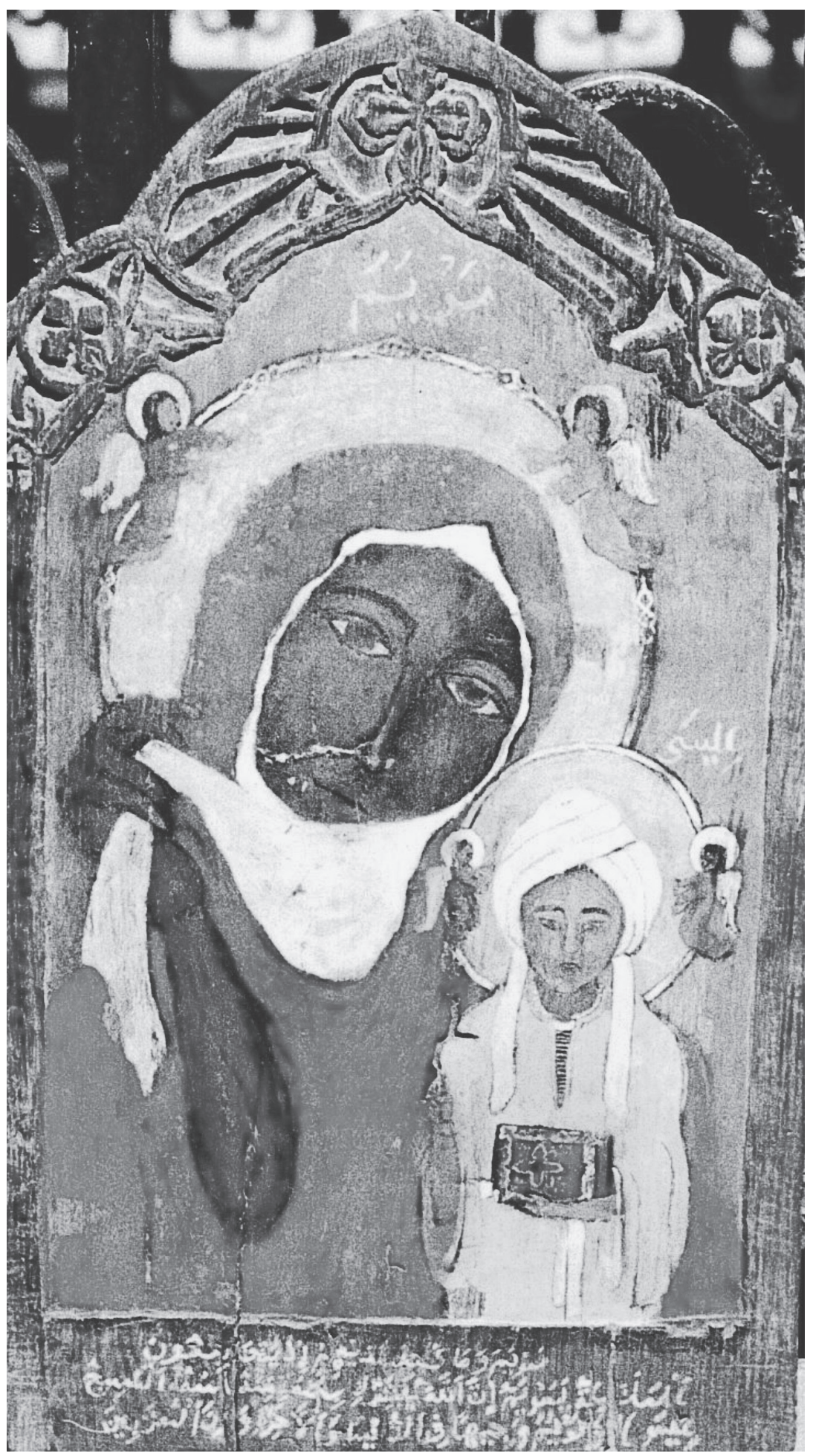

Figura 1. La Virgen con el Niño, interpretación musulmana, Tatáritsa (Bulgaria). 
el icono en realidad es fruto de la acción de sus devotos, más que del taller donde se produjo.

\section{El contexto confesional y étnico de Tatáritsa}

En su artículo, Georgieva dice que según la información proporcionada por el coleccionista, el último poseedor de la imagen, ésta «procede de un pueblo de Bulgaria nororiental con población mayoritariamente turca» ${ }^{9}$. Sin embargo, aparte de los turcos y los búlgaros (a saber, musulmanes y cristianos), en Tatáritsa habitan todavía descendientes de los cosacos del Don que son étnicamente rusos, de confesión cristiana ortodoxa, seguidores del calendario viejo, y que fueron expulsados de Rusia (s XVII) tras las reformas del zar Pedro el Grande ${ }^{10}$. A pesar de las diferencias en lo que concierne a las tradiciones y las costumbres de rusos y cosacos del Don, estos últimos hablan ruso y siempre se han considerado como parte de la Gran Rusia, si bien con cierta autonomía. El movimiento del viejo rito o, en búlgaro, старообредничество [staroobrédnichestvo], que forma parte de su identificación, es un movimiento religioso que se originó en Rusia en el siglo XVII, en oposición a las reformas eclesiásticas del patriarca Nikon; este movimiento predicaba la conservación del antiguo canon, por lo cual sus seguidores son llamados староверы [staroverăy], del ruso, 'antiguos creyentes'. En este sentido, con mayor razón los cosacos se autoconsideran protectores de la iglesia rusa.

El pueblo de Aydemir ${ }^{11}$, del que hoy día forma parte Tatáritsa, nace durante el reinado de los otomanos. Se menciona en los documentos otomanos en 1620 como Aya Timúr ('Santo Timúr'), desde 1675 como Aydemir y, desde 1792, como Aytemir. Conforme al tratado de paz de Bucarest (1913) el pueblo queda en el territorio de Rumania. De nuevo es devuelto a Bulgaria en 1940, gracias a los Acuerdos de Craiova. Unido a la ciudad de Silístra en 1970, seis años más tarde (1976) vuelve a su autonomía.

Durante años, Aydemir acoge a muchos inmigrantes búlgaros, procedentes de diferentes regiones del país (los almaliytsi, del pueblo de Almali (Dobrudzha); grebentsi, de la región de Haskovo ${ }^{12}$; shikovtsi, de la región de Kotel; macedonios; etc.). Hasta los años 40, el otro gran barrio de Aydemir, llamado Delénkite, fue habitado por macedonios aromanes, llamados también valacos (tzíntsaros, kutzovalácos, karavalácos), término utilizado como exónimo para los pueblos romanizados en esta región, pero de fe cristiana ortodoxa ${ }^{13}$.

Después del aplastamiento de la revuelta en Bulavin, un grupo de cosacos de la orilla del Don, encabezados por su líder Ignat Nekrasov, huyó de Rusia, refugián-

Georgieva 2002, 61.

10 Los «rusos del antiguo (o viejo) rito» son el grupo étnico más pequeño en Bulgaria y se concentran en los pueblos de Kazashko y Tatáritsa, donde viven unas 700 personas.

11 Aydemir es el pueblo más grande de Bulgaria, con una población de 6.515 personas; la etimología de su nombre parece turca (de tur. 'Luna de hierro'), pero el mismo nombre también aparece en la «Lista de los nombres de la étnica búlgara», es decir, puede que sea de procedencia protobúlgara.

12 Haskovo es una de las regiones donde fueron deportados los kăzălbashíes, que son musulmanes heterodoxos que se caracterizan por el culto a los santos; sobre esta minoría véase: Spasova Ilieva 2007.

13 Los aromunes emplean diferentes dialectos valacos del idioma arumano (lengua neolatina), usan el alfabeto latino, cirílico y griego, y habitan en los Balcanes meridionales, principalmente en Grecia noroccidental, Albania meridional y la República de Macedonia. 
dose en el territorio del imperio otomano (1674). En consecuencia, «los seguidores de la secta de Nekrasov fundan el pueblo de Tatáritsa» ${ }^{14}$, en el que, en 1881, 264 personas de la población, de un total de 332, se identifican como starovertsi, es decir, cristianos rusos que siguen el «antiguo rito» ${ }^{15}$.

La comunidad se mantuvo muy compacta por razones religiosas, minoritarias y étnicas. Se hizo famosa porque durante largo tiempo no permitió innovaciones en sus ritos, ni matrimonios mixtos, siguiendo estrictamente su antigua tradición, que era muy específica ${ }^{16}$. Los creadores de la comunidad la iniciaron con 16 familias, originarias de las orillas del Don, a las que más tarde se sumaron otras 60 procedentes de Rumania, de la región de Constanza.

La iglesia de Tatáritsa, consagrada a la protección de la Madre de Dios, se construyó en 1750 y no tiene par en el país; la campana, los iconos, los candelabros y los libros litúrgicos procedían de Kiev, del famoso Monasterio de las Cuevas de Kiev (Kievo Pecherska Lavra) en Ucrania. Por su lado, la otra iglesia (de la «Santísima Trinidad»), que se sitúa en el pueblo de Aydemir y fue construida (1829) por los soldados rusos, conserva dos candelabros hechos de fusiles rusos, manuscritos en pergamino e iconos de época, pintados de manera primitiva. Acerca del pueblo de Tatáritsa, en 1842 escribe Sadăk Pasha, así como el historiador Konstantin Jirechek, quien la menciona en 1881.

Pese a su hermetismo, parece que la comunidad de los cosacos no pudo no ser influida, y viceversa, por ese paisaje étnicamente tan diverso, donde se cruzaron ideas y creencias, originarias de Asia, Rusia, Rumania, Turquía, Macedonia y Albania, en una región ya conocida por la numerosa concentración de musulmanes, desde la conquista otomana hasta el día de hoy.

\section{Hipótesis del modelo iconográfico que se había seguido y «los elementos extraños»}

Según Georgieva, la imagen de Tatáritsa imita un tipo iconográfico bien conocido en

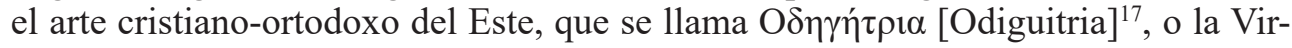
gen Guía, pero en mi opinión, si podemos hablar de un modelo, este sería más bien el de La Virgen de Kazán, que presenta más semejanzas con el icono de Tatáritsa y que también entra en dicha categoría, pese a sus particularidades ${ }^{18}$.

14 En el año 1955 Tatáritsa se une administrativamente al pueblo de Aydemir. Sin embargo, ésta localidad sigue siendo conocida como «el pueblo de los starovertsi»; véase: село Айдемир [selo Aydemir], http://www. aidemir.com/; Boteva 2015.

15 Cabe decir que starovertsi en Bulgaria también se llaman a todos los cristianos que siguen el calendario juliano, entre los cuales también hay búlgaros. La comunidad de los starovertsi en Bulgaria se autoconsidera la única que sigue la ortodoxia y que no cayó en la apostasía, como lo hizo, según sus seguidores, la Iglesia búlgara ortodoxa, aceptando el nuevo calendario juliano (que en parte coincide con el Gregoriano), y los demás compromisos sobre los que los creyentes no están muy informados.

16 Conservadores de una moral estricta, partidarios de la prohibición tajante del alcohol, del tabaco, y de la prohibición de rasurarse la barba. Entre otras particularidades, los «antiguos creyentes», a diferencia de los seguidores de la iglesia ortodoxa rusa de hoy, la búlgara, o los nikonianos, se persignan con dos dedos (índice y mayor), lo que según el canon es herejía.

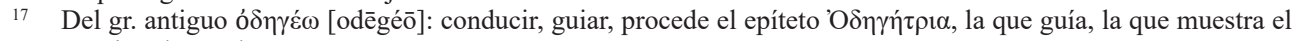
Camino, la conductora.

18 Véase figs. $N^{\circ} 2,3$. 

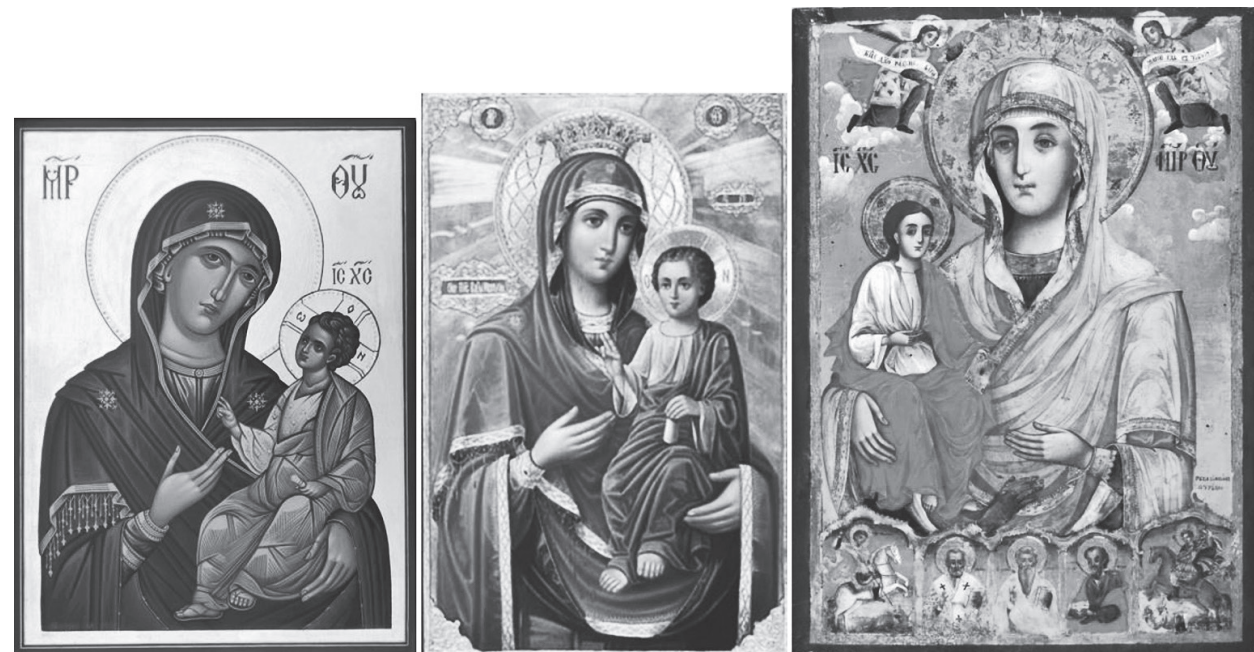

Figura 2. Variantes de tipo Odiguitria: a) icono griego; b) icono ruso; c) Troerutchitsa (de las tres manos), Bulgaria, copia de la Virgen de Hilandar enriquecido con imágenes de santos.
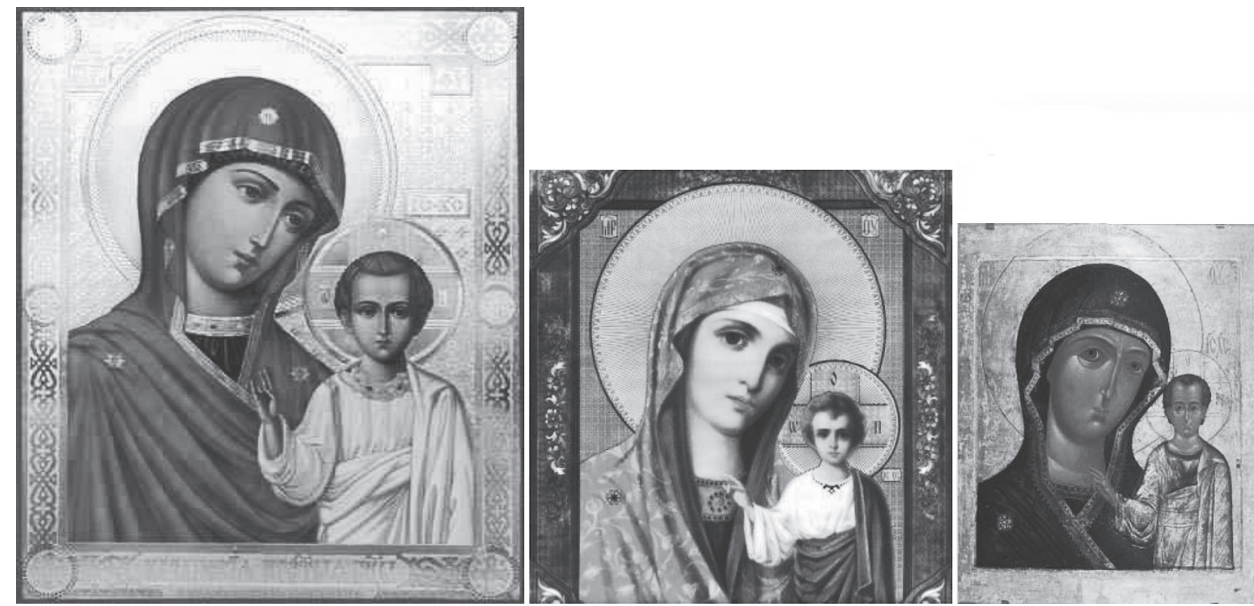

Figura 3. Variantes de La Virgen de Kazán, Kazanska Bogoroditsa.

Las imágenes de tipo Odiguitria representan a María con el Niño Jesús en sus brazos, señalando con la mano derecha al Hijo como el Camino, para indicar a los fieles que la Verdad se encuentra en $\mathrm{É}^{19}$. El Niño aparece sentado sobre el brazo izquierdo de la Madre, brazo que sirve como trono para el Hijo. Con la mano derecha el Niño bendice, mientras que con la izquierda sostiene un pergamino o rollo de las Escrituras. Lo más significativo de ambas figuras es que las miradas de la Madre y del Niño no se cruzan, más bien se dirigen al frente, como si estuvieran mirando algo lejano y sobrehumano. La frontalidad es un rasgo esencial del arte iconográ-

19 En las representaciones de Kazán, la Virgen no señala al Hijo con la mano. Aparece representada en corte pectoral, con la cabeza inclinada sobre el Niño; es la expresividad de los ojos de la Madre de Dios, María, que nos invita a mirar a Cristo. 
fico, y significa que el que lo contempla entra en comunión directa con el personaje celestial. En estas representaciones, la Virgen, como toda mujer casada de esa época, lleva la cabeza cubierta; se ve la cofia de tela, normalmente de color azul celeste. Su vestimenta es el Chitón (vestido o túnica interior) de color azul, que está indicándonos su humanidad. Sobre su cabeza cubierta, lleva el Maphorión ${ }^{20}$, manta o mantilla corta de color rojo, que representa la cercanía de la Virgen a la divinidad, y que le cubre la cabeza, cayendo también sobre hombros y brazos; el borde de la mantilla está enriquecido con galones y flecos en dorado, significando realeza. Sobre los hombros y la cabeza, la mantilla de la Virgen lleva triplemente la cruz en forma de estrella, antiguo símbolo sirio de la virginidad.

En el icono de Tatáritsa, Mariam (María) es representada hasta la cintura, con Isa (Jesús) a su izquierda, al igual que en la imagen de Kazán ${ }^{21}$. Ambos están situados en un espacio en forma de arco. Las inscripciones por encima de las figuras están en árabe, identificándolos como Mariam e Isa (la Madre de Dios y Jesucristo). El torso de Mariam se inclina hacia Él, mientras que su mirada se dirige al orante ${ }^{22}$. Ángeles con ramas en las manos aparecen al lado de los nimbos de ambas figuras ${ }^{23}$, protegidos encima por un arco (conopial de tipo árabe), dividido en tres partes decoradas. En el centro de cada parte se hallan incrustadas cruces; la del centro está rodeada de un círculo del que salen rayos. En paralelo al círculo, el autor diseñó otras dos pequeñas cruces, también encerradas en círculos, de los que salen motivos florales o figuras semejantes a rosetas. Estas cruces aparecen quizás para sustituir a las típicas triples cruces-estrellas, que normalmente vemos sobre el Maphorión de la Madre Guía.

La inscripción de los nombres es rasgo importante en la elaboración de un icono, pues confirma la presencia real. Los nimbos, por su parte, señalan a la trascendencia, es decir, apuntan a un espacio que no es de este mundo. Pero las características comunes con la iconografía ortodoxa de tipo Odiguitria terminan aquí, pues toman una vía diferente con el gesto peculiar de la mano derecha de Mariam.

En el icono de Tatáritsa, Mariam, en lugar de señalar a Cristo, sostiene un velo blanco. Este velo sobresale por debajo de su Maphorión de color púrpura rojizo, y da a entender que estuviera destapándose el rostro ante la mirada del espectador.

El color de su manto responde exactamente al canon iconográfico, representando realeza y la naturaleza divina que asume la Madre de Dios con el nacimiento del Salvador. Pero la cofia azul, que cubre normalmente el cabello de la Virgen, es sustituida por un velo blanco que no sólo cubre la cabeza, sino que parece usarse para cubrir el rostro, aunque el gesto de la mano le preste una cierta ambigüedad ${ }^{24}$.

20 Del griego $\mu \alpha \varphi$ ópıov, abrigo; largo velo de mujer (ropa típica de las mujeres sirias de la antigüedad) que desciende desde la cabeza hasta los pies. El Maphorión de la Virgen (la clámide) es una de las reliquias más importantes asociadas con su memoria, desde el año 474 se encontraba en la Iglesia de Nuestra Señora de Blacherna en Constantinopla.

21 En la imagen de Kazán, el Niño está dispuesto a la derecha de la Virgen María, de medio cuerpo, en una posición rígidamente vertical; viste un manto real de fino tejido dorado, tiene la diestra levantada y bendice el género humano con dos dedos, en tanto su mano izquierda pende, cubierta enteramente por la túnica. El icono original está recubierto con una lámina de plata que cubre la figura y las vestimentas, dejando solamente visible los rostros de la Madre y el Hijo (fig. 3).

22 También en los iconos rusos de tipo Odiguitria (fig. 2b: La Virgen de Smolensk -Smolenskaya- y de Kazán), Jesús está en posición frontal.

23 Comparar con fig. 2c.

24 En una de las vírgenes de Kazán (fig. $\mathrm{N}^{\mathrm{o}} 3 \mathrm{c}$ ), en el lugar de la cofia se ve un velo blanco que se parece a una diadema, pero no tiene la misma función que el de la imagen de Tatáritsa. 


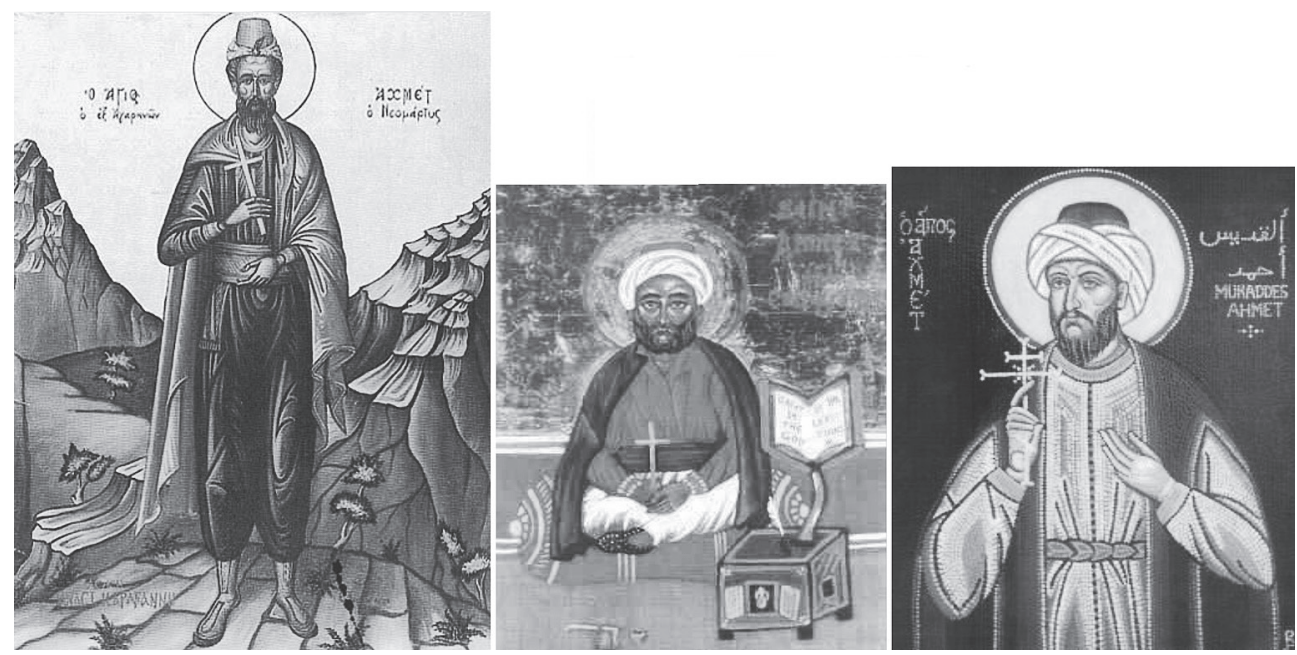

Figura 4. Imágenes de san Ahmet el Calígrafo.

Los velos blancos son muy característicos en las mujeres casadas, árabes y hebreas; el pañuelo de muselina blanca (burqu) en Egipto, por ejemplo, velaba el rostro de las mujeres urbanas, tanto musulmanas como cristianas. Sabemos que en el cristianismo la ropa de color blanco tiene un sentido especial que se relaciona con el renacimiento en el bautismo ${ }^{25}$. La Iglesia copta guarda esa tradición extendiéndola en los oficios religiosos en general; los feligreses etíopes por ejemplo asisten a la misa vestidos de blanco. Generalmente cubren su cuerpo y su cabeza con una tela blanca de algodón que simboliza la pureza; es obligatorio vestir así si se desea recibir la comunión (Spasova Ilieva 2015, 552, 935, figs. n 82). A través del cristianismo, el blanco se convierte en color de la Revelación, de la bendición divina y de la aparición de Dios ${ }^{26}$. La iconografía emplea el blanco también como símbolo que recuerda la promesa de Jesucristo, que dijo que blanquearía los pecados de la humanidad (Isaías 1:18) ${ }^{27}$.

Sin embargo, en el caso estudiado, el velo blanco -y sobre todo en combinación con el gesto especial- es un elemento nuevo y diferente respecto a las imágenes de la Virgen ${ }^{28}$. En cuanto al Niño, en los iconos ortodoxos de tipo Odiguitria viste en colores: blanco, naranja y azul o solamente naranja; donde el blanco simboliza la pureza y la luz de la Transfiguración (la luz increada), el azul la naturaleza humana que Él asume por su nacimiento, y el naranja representa la Verdad, el fuego del Espíritu Santo.

En la imagen de Tatáritsa, los atributos de Isa son típicamente orientales. Su larga túnica, ceñida en la cintura, está teñida de amarillo; la cabeza se toca con un turbante

25 Pues en los primeros siglos el bautismo se llamaba «elucidación», el nuevo bautizado llevaba vestimenta nueva en blanco, como signo de su renacimiento para una vida nueva.

26 En la iconografía ortodoxa, Jesucristo viste de blanco en la Resurrección; en las representaciones de la resurrección de Lázaro, este también aparece con ropa de color blanco.

27 Venid luego, dice Jehová, y estemos a cuenta: si vuestros pecados fueren como la grana, como la nieve serán emblanquecidos; si fueren rojos como el carmesí, vendrán a ser como blanca lana.

28 Son muy pocas las imágenes rusas en las que la Virgen viste el Maphorión o el Chitón blancos. Véase Spasova Ilieva 2015,936 , fig. $n^{\circ} 83$. 
blanco, cuyos extremos caen sobre el pecho. En su mano izquierda sostiene el Evangelio, ricamente decorado, en medio del cual destaca la señal de una cruz; la mano derecha se levanta para bendecir.

Ahora bien, aunque existen notificaciones sobre algunas representaciones en las que Jesús aparece con turbante ${ }^{29}$, si hablamos del contexto balcánico y el eslavo, ese elemento iconográfico de la vestimenta me resulta indicativo de una relación más bien con el islam que con el cristianismo ${ }^{30}$, excepto casos particulares ${ }^{31}$. Pero lo que llama la atención son los rasgos de las caras de las dos figuras, muy insólitos para la tradición ortodoxa. La piel morena y los ojos azules de la Virgen, así como la forma alargada de los ojos de Jesús, insinúan un origen oriental. Como sugiere Georgieva ${ }^{32}$, las imágenes de culto de los antiguos cristianos egipcios, los coptos, podrían ser una buena base de comparación para nuestra imagen; las cruces en la parte superior y la forma del arco que observamos en nuestro icono de Tatáritsa, son muy característicos del arte oriental ${ }^{33}$. Otro vínculo más, que relaciona el icono de Tatáritsa con el arte copto, es la falta de barniz sobre la pintura. Sin embargo, también puede tener relación con la iconografía de Etiopía, en donde se representan a las vírgenes morenas. Los ojos almendrados conducen hacía un paralelismo con las miniaturas orientalistas pero también desempeñan un papel importante los colores básicos aquí utilizados como el ocre, el rojo, el blanco y el marrón y sus matices. «La manera de poner los tintes sobre campos amplios y lisos, sin sombras, el contorno enfatizado por su parte, hace que la imagen se parezca a un simple dibujo coloreado. Dichos elementos son muy característicos también de las miniaturas orientales, la persa y la turca en concreto» ${ }^{34}$.

«La falta de oro en los nimbos, uno de los elementos principales de la simbólica ortodoxa (bizantina), también puede llevar a la hipótesis de que el icono fue elaborado en una región en la que se desconocía esa técnica, apuntando así a un periodo anterior de la creación de la imagen $»^{35}$. Cabe recordar que el color del oro no es un color que podamos encontrar en la naturaleza; de esta manera el fondo dorado o los nimbos dorados sitúan a las imágenes de los iconos ortodoxos en un espacio donde los cuerpos ya no tienen que respetar los elementos del paisaje, de manera que estos se encuentran liberados de lo terrestre, volviéndose espirituales. A través del nimbo, el icono transmite el fenómeno de la luz que desprenden las caras de los santos en momentos de alabanza sublime (Sal 34:30; 2 Cor 3:7-8). La aureola no es una alegoría, sino expresión simbólica de una realidad concreta, es una parte inseparable del

29 Vladimirskiy1998, 100-124; Georgieva 2002, 62.

30 Según mis observaciones, el turbante en la iconografía ortodoxa del Este indica una conversión del islam al cristianismo o bien un mártir cristiano forzado para aceptar el islam, ambos casos concluidos con una ejecución por el testimonio público de la fe cristiana. Así por ejemplo se puede ver en los iconos del mártir San Ahmet el Calígrafo (s. XVIII, fig. 4), del mártir san Tunom (o Amir, s. XVII, fig. 5a, ambos estudiados detalladamente en: Spasova Ilieva 2015, 410,415, 419-424), del mártir San Feodor Mitilenskiy (santo bizantino, s. XVIII, fig. 5b), o de San Juan Damasceno (fig. 5c).

31 En la iconografía ortodoxa, con turbante idéntico al del icono de Tatáritsa encontramos a santa Raquel (segunda

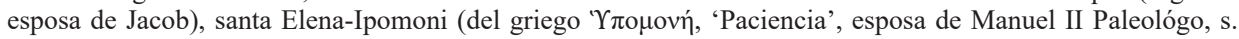
XIV), y santa Emilia, madre de san Basilio el Grande (véase figs. 5e). Con una especie de turbante, pero muy diferente de lo estudiado, son representados san José con el Niño en un icono etíope (fig. 5d).

32 Georgieva, 2002, 62.

33 El mismo arco con las cruces en la parte superior, al igual que en el icono de Tatáritsa, he encontrado en un icono copto que representa «El Bautismo de Cristo», véase Spasova Ilieva 2015, 936.

34 Georgieva 2002, 62.

35 Georgieva 2002, 62. 

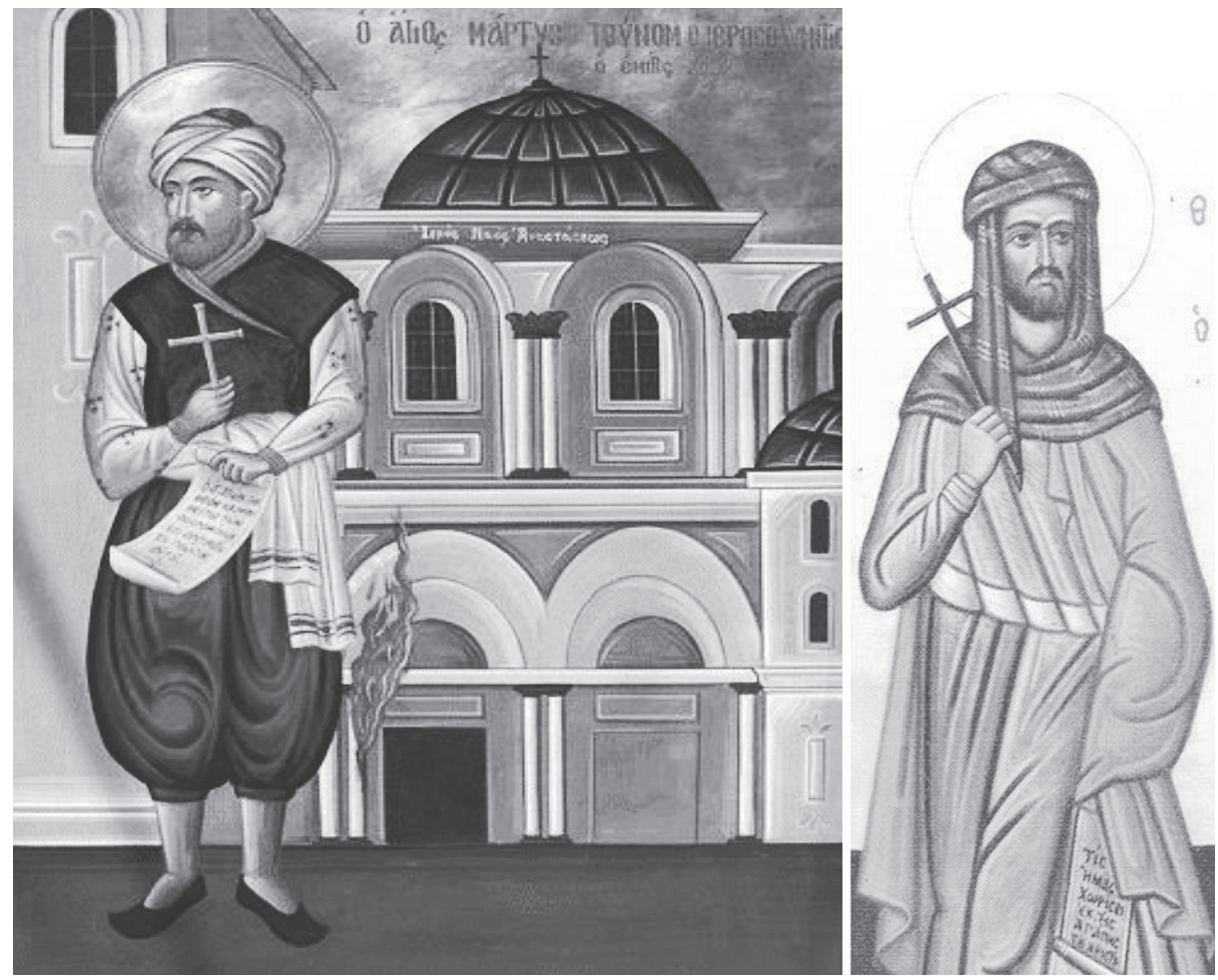

Figura 5. a) El santo mártir Tunom y al fondo la columna encendida. Icono portátil que se encuentra en el monasterio de la Virgen de Jerusalén; b) santo mártir Feodor Mitilenskiy (de la isla de Lesbos, dcha.);
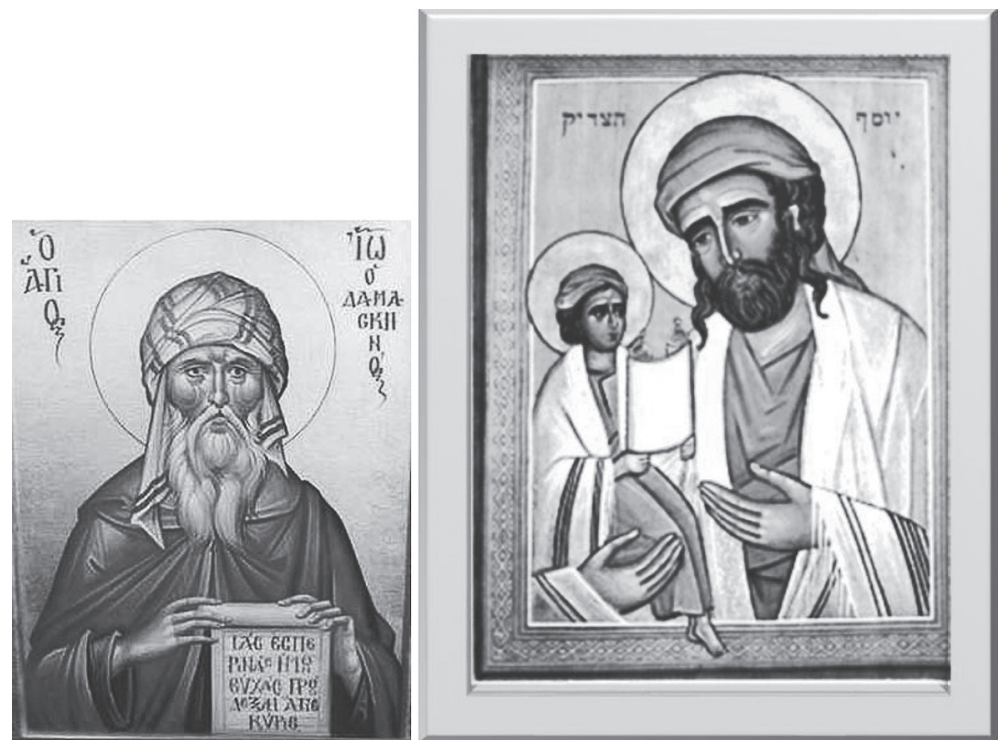

Figura 5. c) san Juan Damasceno; d) san José y El Niño Jesús, ambos tocados con una especie de turbante, icono ortodoxo copto (dcha.); 

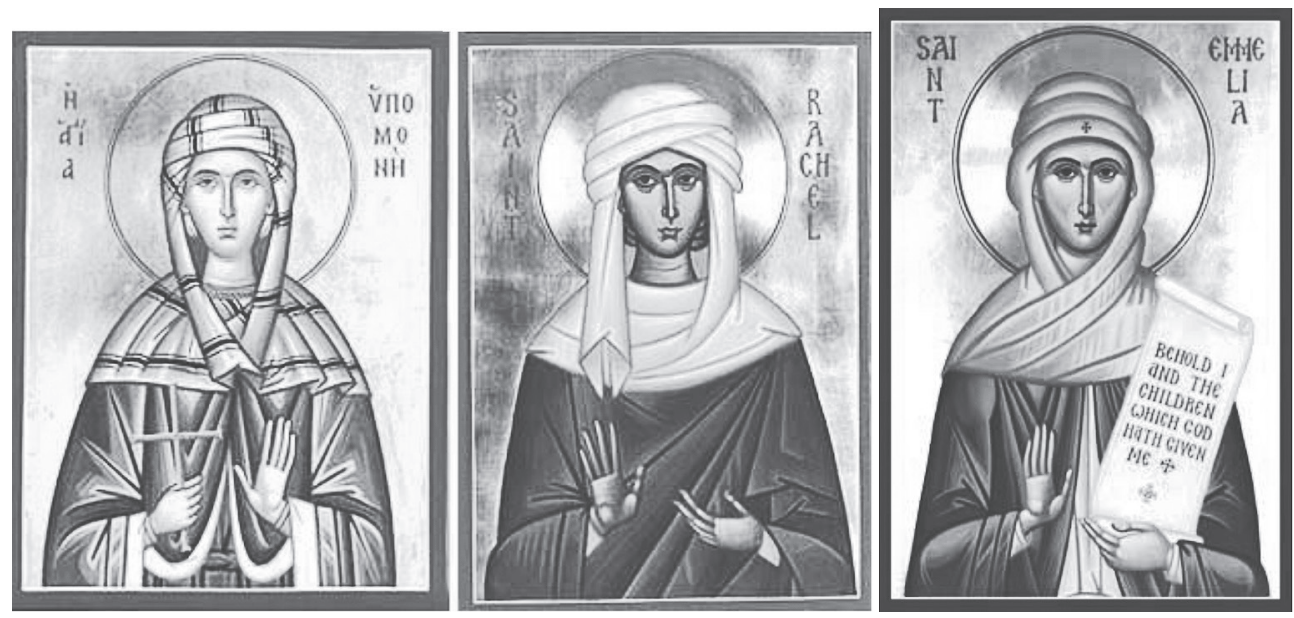

Figura 5. e) santa Elena-Ypomoni (Paciencia), santa Raquel, santa Emilia (dcha.)

icono, necesaria, pero no suficiente, pues ha sido empleada no exclusivamente para mostrar la santidad cristiana: los paganos también representaban a sus emperadores y dioses con aureolas para destacar su carácter divino. Por eso, la aureola no es el único signo que diferencia al icono de las demás imágenes: es una herramienta iconográfica que testimonia la luz, y si la aureola fuera eliminada de un icono ortodoxo o no se viera, este último seguiría siendo un icono gracias a sus formas, contornos y colores que sugieren indirectamente el estado interior del hombre.

En nuestro icono, los nimbos no son dorados, están sólo teñidos en amarillo, que para los cristianos también es un símbolo importante que remite a Jesucristo, la vida eterna y la $\mathrm{fe}^{36}$. A diferencia del amarillo, el oro no tiene su propia tonalidad material; es el reflejo puro de la luz, es el brillo; y si los otros colores reciben su vida y su sentido a través de la luz, el oro tiene su propio brillo ${ }^{37}$, por lo tanto desempeña un papel importante en la iconografía. Es un símbolo de la luz divina que es fundamental en el icono ${ }^{38}$, porque el icono en su doxología canta la gloria, y el atributo de la gloria es la luz; como cantan las iglesias balcánicas en la noche de Pascua, «todo está lleno de luz increada, el cielo, la tierra, el infierno» ${ }^{39}$.

Pero en efecto, el valor y el nivel de cada símbolo están profundamente relacionados con el valor y el nivel de la razón que los utiliza, pues, según san Dionisio el

36 Sin embargo, en la descripción de las jerarquías celestiales y terrestres, para cuya comprensión san Dionisio el Areopagita utiliza la simbología de los colores, el amarillo no tiene lugar, aunque en cierta ocasión el mismo autor habla de $\chi \rho v \sigma o \varepsilon 1 \delta \varepsilon ́ \varsigma$, el 'oro amarillo'; para él, dicho color está demasiado cerca del brillo blanco y del brillo dorado para que tenga su propio simbolismo. Si podemos decir que el oro es equivalente a la luz y no tiene su propia tonalidad material, el amarillo sí la tiene; en su forma más pura, de limonado, en la iconografía ortodoxa el amarillo irradia una tristeza tenue, visible en el icono de Cristo cuando se Le coloca en la tumba (ejemplar de la escuela de Novgorod). Esa característica del color parece ser confirmada por las Santas Escrituras, donde es un signo de una mala cosecha, o para la fiebre (Dt. 28: 22, Ag. 2:7), e incluso la lepra (Sendler 2005, 69).

37 Sendler 2005,69.

38 Por eso, el icono bizantino representa a Cristo resucitado, en la Metamorfosis del Monte Tabor con toda la luz increada; en cambio, las representaciones occidentales del Salvador desde finales de la Edad Media representan su naturaleza mortal (Jrisoulas 2014).

39 Jrisoulas 2014. 
Areopagita, «el poder y la utilidad del símbolo parece ser movedizo y ambiguo» ${ }^{40}$, y «prácticamente, un mismo color puede tener diferentes significados simbólicos en los diferentes niveles de la jerarquía celeste» ${ }^{41}$.

Lo que es evidente en este caso es el modelo que se estaba siguiendo, la buscada cercanía al canon iconográfico ortodoxo en cuanto el uso de los colores, y al mismo tiempo, la interpretación personal por parte del pintor de aire oriental y sincrético.

Técnicamente, la diferencia básica entre esta iconografía y la clásica consiste en la ausencia de un soporte pictórico ${ }^{42}$ que normalmente se coloca debajo de la capa de pintura, y la existencia de tal soporte en la parte trasera de la madera ${ }^{43}$. En fin, después de los análisis microquímicos que se realizaron, se concluye que, para aglutinante del pigmento rojo y del amarillo, se utilizó cera, una técnica muy antigua,

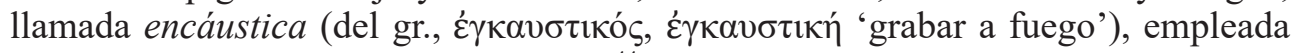
sobre todo en Egipto, Siria y Palestina ${ }^{44}$. Ahora bien, lo interesante es que el pigmento blanco tiene una estructura distinta para la cual se utilizó otro tipo de aglutinante, lo que data el icono a principios del siglo $\mathrm{XX}^{45}$ y parece apoyar la hipótesis de que el velo blanco fuera añadido más tarde, bien como parte de la conservación de la pieza o bien para modificarla. Y aunque esto es sólo una suposición que necesita de más pruebas técnicas, resulta muy verosímil si se tiene en cuenta el contexto tan abigarrado donde se encontró el icono.

Una pista aceptable acerca de la influencia musulmana y cierta explicación sobre los rasgos orientales de las figuras nos las puede proporcionar la profundización en el origen de las comunidades que habitan en Tatáritsa.

\section{Influencias musulmanas; tártaros y cosacos}

Antes de nada se debe tener en cuenta que el término cosaco es más bien una categoría social que histórica ${ }^{46}$. En cuanto al origen de los cosacos del Don, compiten varias teorías:

[Según la primera] los cosacos del Don son campesinos fugitivos [...] de diferentes orígenes étnicos, rutenios ${ }^{47}$, turcos, alemanes. La necesidad de defender su estilo de vida (pirateo, pesca y caza irregular) y de proteger sus asentamientos de los ataques de los tártaros, mongoles y otras tribus nómadas que vivían en las estepas del sur de Rusia, forzó a estas bandas de huidos a organizarse en una sociedad militar $[\ldots]$ que protegía las fronteras meridionales de la Rusia medieval [...] La [otra] hipótesis sugiere que los cosacos del Don no migraron a las estepas del sur de Rusia desde otras partes de Europa, sino que son los descendientes de

\footnotetext{
$40 \quad$ Sendler 2005, 63.

41 Sendler 2005, 63 .

42 Superficie previamente tratada con una mezcla especial, sobre el que se aplica la pintura.

43 Georgieva 2002, 62.

44 Los pigmentos encontrados son el rojo-cadmio: el pigmento entra en uso en 1912; y el amarillo-cromo: el pigmento entra en uso en 1809, muy aplicado en el siglo XIX (Georgieva 2002, 63).

45 Georgieva 2002, 64.

46 Se usaba ampliamente para designar a «personas libres» por oposición a otras, con diferente prestigio en una sociedad feudal, pero la palabra «cosaco» también se aplicaba a los nómadas, filibusteros y bandidos.

47 También rusinos, carpato-rusos y rusniakos.
} 
los protoindoeuropeos que emigraron a esta área desde el Cercano Oriente antes de las sucesivas migraciones a Europa e India. Las teorías, sin embargo, no se excluyen mutuamente. Es posible que los cosacos del Don se originaran como descendientes de los protoindoeuropeos y con el tiempo dieran cobijo a gentes de diversos orígenes étnicos que, por diferentes motivos [p. ej. religiosos], escapaban de su tierra natal hacia el territorio de los cosacos del Don ${ }^{48}$.

Después de lo dicho, lógicamente viene la pregunta acerca de qué papel desempeña entonces el topónimo Tatáritsa (tatári, de búlg., 'tártaros', en tárt.: Татарлар [Tatárlar]) que inmediatamente remite a los tártaros, que, como es sabido; fueron enemigos feroces de los cosacos. La respuesta a esta cuestión aclararía parte de la controversia de por qué una comunidad de fe cristiana funda un pueblo con nombre de connotación musulmana, pues los tártaros en Bulgaria siempre se relacionan con el islam.

Resulta que, fuera de las fronteras del país, el término «tártaro» se aplica a pueblos turcos de Europa oriental y Asia, entre los cuales hay muchas diferencias ${ }^{49}$. Hoy día entre los tártaros hay musulmanes, pero también cristianos ortodoxos, concretamente en Rusia, aunque muchos de ellos no son «practicantes». Sin embargo, la connotación musulmana que transmite el nombre «Tatáritsa» es explicable ya que, especialmente para Bulgaria, se sabe que éstos encontraron refugio en el país, huyendo de los rusos. La política de Rusia sobre los tártaros fue muy cruel y hostil, estos últimos fueron forzados a convertirse al cristianismo y a adoptar la lengua rusa. Como consecuencia, fueron casi completamente asimilados; los que llegaron a Bulgaria buscaban protección contra la conversión forzada.

El origen del nombre de los tártaros designa un antiguo pueblo túrquico que, en el siglo XI, vagaba entre la parte oriental de Mongolia y el actual Kazajstán. De todos modos, el antiguo pueblo tártaro como tal ha desaparecido, los descendientes se mezclaron con la gente de los territorios que conquistaban. Su nombre fue traspasado a las poblaciones de dichos territorios que hoy reúnen diversos orígenes, como los tártaros de Kazán o los de Crimea. Así por ejemplo los tártaros de Kazán son descendientes de los búlgaros del Volga, pero tras la captura por las Hordas de Oro, se llega a crear el Kanato tártaro de Kazán, aunque hasta la Revolución de Octubre, los habitantes de Kazán no dejaron de llamarse búlgaros ${ }^{50}$. Hoy día, Kazán es la capital de la República de Tartaristán en la Federación Rusa, donde también en 1579 se descubrió entre las cenizas el icono de Nuestra Señora de Kazán (Казанская икона Божией Матери), que según mi hipótesis, ése era el modelo que se había seguido por el pintor del icono estudiado, o al menos, al que más se parece.

Cabe decir que la imagen de Kazán está entre las más veneradas en toda Rusia, conocida como «La Libertadora y Protectora de la Santa Madre Rusia»; la Virgen de Kazán fue utilizada en todas las crisis nacionales cuando la victoria rusa le fue directamente atribuida por el pueblo. No sé si es casualidad el hecho de que fueran los cosacos del Don los que impidieran el saqueo de la plata a los franceses en las iglesias de Moscú en 1812, y la entregaran como donación al icono de la Virgen de Kazán en San Petersburgo. En la Catedral consagrada a su protección, éstos coloca-

\footnotetext{
48 Kliuchevskiy, 455.

49 Pues, era tradición de los gobernantes rusos llamar a todos los pueblos musulmanes en Rusia, tártaros.

50 Se refiere a los «búlgaros de Volga».
} 
ron un iconostasio de plata, que llevaba la inscripción:»Ofrenda diligente del ejército del Don ${ }^{51}$.

El nombre de tártaros, dado a los invasores, se extendió posteriormente a otros miembros de la misma rama turco-mongol en Rusia, incluso hasta el punto de que la mayoría de los habitantes de la meseta de Asia quedó definida bajo el nombre genérico de Tartaria, fenómeno que puede ser aplicado al nombre del pueblo de Tatáritsa en Bulgaria, habitado por cristianos, pero étnicamente rusos. No obstante, eso no fue sin fundamento alguno, pues los tártaros también asimilaron desertores de los ejércitos enemigos, ruso, polaco o de otro tipo, así como a nómadas. Mezclados a lo largo de los siglos con los mongoles y los eslavos- los tártaros se distinguen de los turcos osmanlíes (de Anatolia) por un fenotipo más asiático: a menudo observamos allí ojos alargados así como pómulos salientes, otros son rubios con los ojos azules como los eslavos, esto nos proporciona una posible clave para el enigma de los rasgos orientales, tan insólitos para las figuras de la Virgen y el Niño, representados en nuestra imagen: piel morena, los ojos azules de María y los ojos almendrados de Jesús.

Teniendo en cuenta el lugar del hallazgo del icono y los vínculos históricos de los cosacos rusos con los tártaros, creo que una influencia musulmana, desde luego resultado de un criptoislam o bien criptocristianismo, por parte de esos últimos, puede ordenar el rompecabezas. Probablemente el icono fue traído de la tierra de los antepasados de los habitantes de Tatáritsa, hecho por un criptotártaro (convertido al cristianismo) o bien por un cristiano cosaco, medio asimilado por los tártaros. Lo que me permite hablar de tal asimilación son las fuentes escritas sobre los tártaros entre los cosacos del Don, referidas al periodo 1603-166052. Por estas fuentes se sabe que, excepto los de clara ascendencia rusa, entre los cosacos se encontraban personas de orígenes muy diferentes y que muchos de ellos ni siquiera eran ortodoxos. En este sentido es significativo que en 1632 los cosacos del Don se negaran a prestar juramento en Moscú, ya que entre ellos había muchos «busurmanes» (musulmanes) que no podrían «besar la cruz», preceptiva en el rito de juramento cristiano. También, en los informes de las bajas de cosacos en Moscú, del año 1658, encontramos declaraciones como la siguiente:

Los que [...] viven con nosotros en el ejército, extranjeros inmigrantes - turcos, tártaros, también griegos, y otra gente de tierras diferentes, que se desplazan a nosotros, a las tropas en el Don [...] y que están en servicio, viviendo aquí en el ejército, en servicio estatal junto a nosotros ${ }^{53}$.

Así pues, en el ámbito de los cosacos había personas de orígenes étnicos completamente diferentes, incluso moros ${ }^{54}$, circunstancia que cambia el punto de vista respecto al turbante del icono estudiado si se acepta una procedencia tártaro-cosaca ${ }^{55}$. Pese a la diversidad de las etnias, en los registros de los cosacos el primer lugar lo tenían los tártaros porque sólo ellos se diferenciaban como un grupo peculiar de

\footnotetext{
Чудотворни икони на Пресвета Богородица 2006, 215.

Kuts 2006, 398-414.

Kuts 2006, 414.

«Así, un moro fue detenido entre los cosacos de Crimea y de Don en 1662 durante el ataque de los cosacos por mar cerca de Kerch», Kuts 2006, nota 4.

55 Sin olvidar que los judíos en el imperio otomano por ejemplo, también llevaban turbantes (amarillos).
} 
la población del Don, llamados tártaros del Don. En los informes del siglo XVII donde se menciona a los tártaros del Don que estaban al servicio de los cosacos, este grupo es llamado «nuestros tártaros», «del Don» ${ }^{56}$, separándolos de esa manera de los cosacos enemigos, representantes de los pueblos de habla turca ${ }^{57}$. Esa denominación amistosa, que dieron los antiguos cosacos del Don a sus vecinos con los que se codeaban a diario, traza una línea de separación entre los diferentes clanes, y da un giro a nuestras reflexiones para hallar una explicación aceptable sobre la ambigua denominación de los «cosacos» de Bulgaria, que tiene una connotación musulmana, pero que se explica por el contexto histórico. Mucho después, otra causa pudo haber unido a cosacos y tártaros del Don: tras la derrota del Ejército Blanco en la Guerra Civil Rusa, tuvo lugar un plan de disolución de los cosacos supervivientes (el así llamado разказачивание razkazáchivaniye ${ }^{58}$ ), desarraigándolos de sus tierras originarias, pues «eran vistos como una amenaza en potencia sobre el nuevo régimen soviético» ${ }^{59}$ Las relaciones entre ambos grupos resquebrajarían el hermetismo religioso, a pesar de que la mayoría de los tártaros ya hubieran sido cristianizados. En un contexto semejante es muy probable que una obra artística que posee influencias musulmanas pueda estar reflejando tendencias universalistas, recordando la observación de Marco Polo ${ }^{60}$, quien decía que «los tártaros, no se preocupaban por saber cuál es el Dios que se adora en su territorio», y el nieto de Gengis Kan, Qubilay Kan, quien incluso pedía las oraciones de todas las confesiones de su imperio. Pues, en el concepto de su hermano, Kan Mongke, «todas las religiones son como los cinco dedos de una misma mano» ${ }^{61}$.

Pero lo que me permite hablar de indudables influencias musulmanas en la imagen de Tatáritsa es la cita coránica en la parte baja de la madera, que está tomada de la azora $\mathrm{Al} \mathrm{Imran}{ }^{62}$, es decir, la familia de la que procede Mariam y, consecuentemente, Jesús (C., 3: 43-44).

Toda la azora y sobre todo las aleyas que no aparecen en la inscripción del icono llevan el significado de lo que representa la imagen. Así pues, la aleya 42, que precede a la cita empleada en el icono, se refiere a María como elegida entre las mujeres de todos los pueblos:

Y cuando los ángeles dijeron: ¡María! Alá te ha escogido y purificado. Te ha escogido entre todas las mujeres del universo.

En la aleya 45 de la misma azora aparece el anuncio del nacimiento de Jesús:

Cuando los ángeles dijeron: ¡María! Alá te anuncia la buena nueva de una Palabra que procede de Él. Su nombre es el Ungido, Jesús, hijo de María, considerado en la vida de acá y en la otra y será de los allegados.

\footnotetext{
Kuts 2006, nota 5 .

Tártaros nogayos, tártaros de Crimea, así como turcos.

Sobre esta política y sus consecuencias, véase Magner 1999.

«Durante 1919 y 1920, de una población de aproximadamente 1,5 millones de cosacos del Don, el régimen bolchevique mató o deportó una población estimada entre 300.000 y 500.000 cosacos» (Kort 2001, 133). De hecho, el mencionado pueblo búlgaro de Kazashko fue establecido por cosacos deportados desde Rusia.

61 «Los tártaros no se preocupaban por saber cuál es el Dios que se adora en su territorio. Basta con que todos sean fieles al señor kan, muy obedientes, que paguen los impuestos fijados y se mantenga bien la justicia, [por lo demás] con vuestra alma podéis hacer lo que os plazca», Polo 1982, 70.

62 La cita ha sido descifrada por la otomanista Stoïanka Kenderova.
}

60 Polo1982, 70. 
La inscripción concreta que aparece en el icono está tomada de los versos 43 y 44 y remite a la devoción a Dios a través de la figura de María, que para los cristianos es Madre de Dios y en el islam una de las tres mujeres elegidas por su perfección:

¡María! ¡Ten devoción a tu Señor, prosternaste e inclínate con los que se inclinan! Esto forma parte de las historias referentes a lo oculto, que Nosotros te revelamos. Tú no estabas con ellos cuando echaban suertes con sus cañas para ver quién de ellos iba a encargarse de María. Tú no estabas con ellos cuando disputaban (C. 3: 43-44).

La devoción aquí es la palabra clave, puente entre las dos tradiciones. Los iconos ortodoxos precisamente pretenden: 1) despertar la devoción en los fieles hacia Dios, a través de la Virgen, Jesucristo o los santos que se representan en ellos; 2)

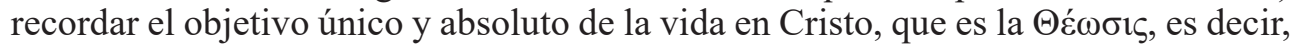
la unión con Dios ${ }^{63}$, de modo que el hombre, participando de la energía increada de

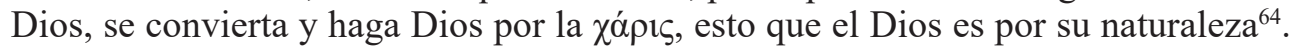
María, mencionada en la azora coránica, para los cristianos es la más santa entre

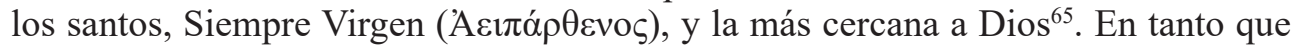

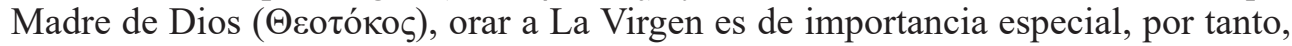
es ampliamente representada en la iconografía ortodoxa y a ella se alude con mucha frecuencia en los himnos y durante la liturgia. Por otro lado, la figura de Isa (Jesús), 36 veces mencionado en el Corán, y la figura de su madre Mariam (María), 34 veces mencionada en la misma escritura sagrada para los musulmanes, son dos de los más importantes puntos en común que trazan lazos entre la tradición bíblica, la del Nuevo Testamento, y la musulmana. En fin, el hilo sutil entre el cristianismo y el islam en la esfera de la mística pasa equitativamente por la figura de Jesús, donde todo puede tomar matices diferentes, según el receptor que los interpreta.

\section{5. ¿Santidad compartida o caso herético?}

Pero más que una representación piadosa, el papel de la imagen cristiana es el

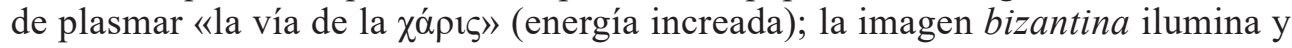
santifica a quienes la contemplan, porque la Xópıs del Espíritu Santo que acompañaba al santo en su vida queda «impresa» en su representación. Puesto que esa energía increada no puede ser representada mediante herramientas humanas, ya que la santidad no se ve ni se reconoce por los sentidos, por ello se establecen estrictas formas simbólicas que distinguen el icono y hacen referencia al uso de los colores y a la disposición de las imágenes, pues el icono es una "escritura» de lo espiritual, una oración en imágenes y colores. En este sentido, la Iglesia Orien-

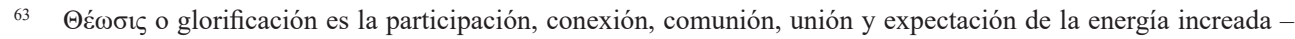
Xápıৎ- con el hombre, permitiendo con ello tomar parte en la vida y la gloria increada de Dios en relación con

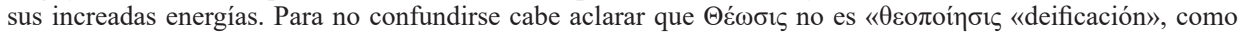
muchos lo interpretan, pues no es un acto que hace el hombre por su propia cuenta (para edificarse en Dios), sino el hombre se prepara y Dios actúa; el acto lo hace Él, no el hombre.

64 Gh. Metalinós 2014.

65 Estos dogmas relativos a María los comparten todas las Iglesias cristianas primitivas, como la armenia y la copta, incluida la Iglesia de Roma. 
tal considera el icono ortodoxo un acto conciliar de toda la Iglesia, y no una obra de arte personal.

En la imagen de Tatáritsa, la simbiosis de los elementos simbólicos procedentes de dos tradiciones, la cristiana y la musulmana, que se refleja en los colores, las inscripciones y los rasgos de las imágenes, permite que sea objeto de veneración para los devotos de una y otra religión, lo que lleva a sospechar una santidad compartida. Sin embargo, podría tratarse de un caso de sincretismo que aúna rasgos simbólicos y, por lo tanto, no deja de estar al margen de la ortodoxia de ambas confesiones religiosas, siendo en buena medida herético tanto para una como para otra.

La inscripción árabe situada debajo de las imágenes en la «obra» de Tatáritsa es algo que interfiere en la «lectura» normal de un icono ortodoxo, aunque hay que reconocer que para la elección precisamente de esa azora y no de otra, el autor debía de conocer bien la doxología del icono por un lado y, por otra parte, también a sus eventuales destinatarios. Claro está que lo llamativo no es tanto el hecho de que aparezca una inscripción en árabe: la novedad estriba en la aplicación de la cita coránica a personajes prominentes de la tradición cristiana, aunque también pertenezcan a la musulmana. En este sentido es un caso excepcional.

Tomando en cuenta la prohibición sobre las representaciones de Dios o de los profetas en el islam, y el conocimiento de la lengua árabe por el autor, Georgieva ${ }^{66}$ considera que el icono fuera realizado por un cristiano que vivía en el Oriente, y que conocía la iconografía ortodoxa, pero representó a los personajes con un aire cercano a su ambiente. Las cruces talladas sobre la madera en la parte superior del icono son otro dato que vincula al autor con el cristianismo.

Respecto a la prohibición de representaciones en el islam, hay que señalar que el Corán no apunta nada en este sentido. La tradición musulmana informa de que cuando Muhammad entró en la Meca en 630, ordenó la eliminación de todos los ídolos que se encontraban en el templo de la Caaba, así como de los frescos que había en las paredes, que probablemente habían sido de contenido bíblico. No obstante, se sabe que el mismo Muhammad mandó que se guardase la imagen de la Virgen María con el Niño Jesús, que lucía sobre una columna del templo, que allí quedó hasta el incendio en 683. Este hecho demuestra que los actos de Muhammad no se dirigían contra la pintura y la escultura como tales, sino contra los ídolos -símbolos de algunos dioses- ante los que se prosternaban las diferentes tribus árabes. Aun así, las prohibiciones y las limitaciones en los diferentes periodos y las diferentes regiones del mundo musulmán en cuanto al arte pictórico fueron interpretadas de manera variable. En el siglo IX en los hadices aparecen textos en los que se prohíbe la representación de Dios y de las personas vivas ${ }^{67}$. Pero las miniaturas de diferentes estilos que representan a La Virgen María con el Niño, de origen árabe, persa, turco e indio hasta hoy conservadas, no solo atestiguan casos de quebrantamiento de dicha prohibición, sino que los pintores, inspirados en pasajes del Corán, representaban a Jesús y a su madre, reflejando en ellos esos episodios coránicos, al modo de su región originaria (Fig. 6).

66 Georgieva 2002, 64.

67 ¡Cuídense de las imágenes del Señor o del hombre, pintad sólo árboles, flores y objetos inanimados!, véase: M. Issa 1996, citado en Kenderova 2002, 46. 


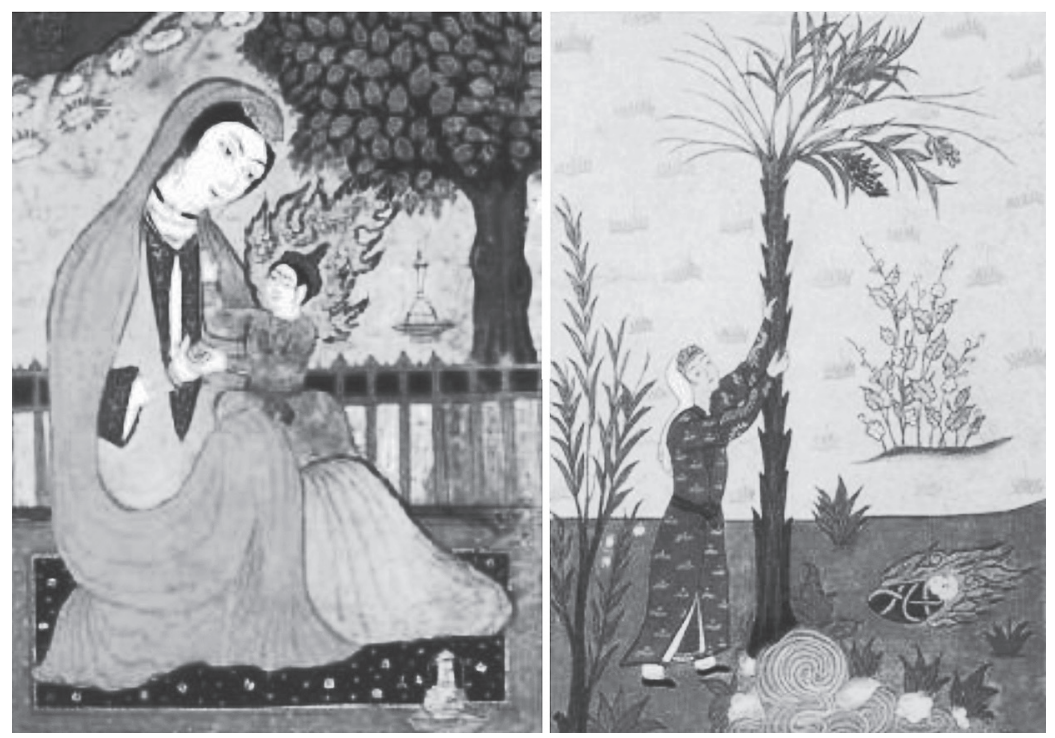

Figura 6. Escenas del Corán: a) Mariam e Isa sobre sus rodillas, miniatura india, s. XVI, Museo del arte en Róterdam; b) Mariam e Isa bajo la palmera (C. 19:23-26), miniatura persa, s XVI.

Pero si la fuerza de la prohibición de las imágenes en el islam variaba según lugares y circunstancias ${ }^{68}$, la escritura coránica en cambio siempre gozó de una inmensa devoción legítima; ya se dijo que al ser recitado en su forma originaria, el Corán es fuente de bendiciones, ya que por cada letra pronunciada se recibe una gracia divina.

De modo semejante, el icono para el cristiano ortodoxo es un signo de la presencia de Dios y la concreción más simple e inmediata de la concepción de la Iglesia, según la comprensión de los pueblos bizantino, eslavo, y los que han sido influidos por ellos.

Del mismo modo en que la letra coránica es inimitable en su estilo, forma e impacto espiritual, para el cristiano el impacto ante el icono es inmenso porque muestra el cuerpo del hombre santo, liberado de la carne pecaminosa. Así pues, como el icono es camino y herramienta hacía Dios para el cristiano, así mismo lo es la escritura sagrada, es decir, el Corán para los musulmanes. De manera que el iconógrafo que pintó la imagen de Tatáritsa empleó, por una parte, el lenguaje del cristianismo oriental, y por otra, el «lenguaje» del islam, logrando así de modo simbólico la unión de ambas tradiciones en un sincretismo peculiar.

El autor del icono, fiel a la idea universalista que tiende a unir a todos los monoteísmos, escogió acertadamente la azora Al Imran. En ella se relaciona a María, madre de Isa (Jesús), con Imran, el padre de Musa (Moisés), donde María es la hija de Imran, respectivamente hermana de Moisés. Tal como aparece en el texto coránico, en la noticia sobre María se mezclan narraciones procedentes del Antiguo Testamento con tradiciones cristianas, lo que hace sospechar de una mala compren- 
sión de los textos originales ${ }^{69}$ : porque María, la madre de Jesús, no tiene hermano de nombre Harón-Aarón-, pero los «bíblicos» Moisés y Aarón, si tenían una hermana que se llamaba Miriam -María-, que es tenida por profetisa. En esta misma azora aparece la promesa de la madre de María, aún encinta, de ofrecer lo que hubiera de venir al servicio de Dios (C., 3: 35-36), historia que se corresponde con la versión cristiana. Sin embargo, en el texto coránico la madre de María es llamada «la esposa de Imran».

«Algunos autores consideran que no se trata de un simple error, sino de una sofisticada metáfora estilística que de ese modo funde dos estirpes ${ }^{70}{ }^{70}$ la de Moisés, descendiente de Abraham, y la de María, madre de Jesús, insistiendo en la filiación judeo-cristiana.

La misma azora III también relaciona a Zacarías, padre de Juan Bautista, con la joven María en su servicio al Templo (C., 3: 37-41), relato que tiene sus conexiones con el evangelio de Lucas y también con el Protoevangelio apócrifo de Santiago ${ }^{71}$, que son fuentes importantes para los cristianos en relación con el nacimiento de María y sus padres ${ }^{72}$.

Entre los rasgos que el Corán aporta acerca del nacimiento y la educación de María, aparecen motivos como el de hilar un velo para el templo y ser escogida para ello echando suertes entre las jóvenes aspirantes (C., 9: 17; 3: 44), que sin duda proceden del Protoevangelio de Santiago, que relata detalladamente el mismo hecho ${ }^{73}$.

En fin, las habilidades milagrosas de Jesús también son reflejadas en dicha Sura ${ }^{74}$. Estos y otros paralelismos entre motivos cristianos y musulmanes apuntan a la idea universalista que probablemente quería transmitir el autor del icono escogiendo precisamente la cita de la azora III.

\section{El gesto inaudito de Mariam}

Aparte de la escritura coránica, en la imagen lo que despierta gran interés es el gesto inaudito de Mariam. El detalle de quitarse el velo es un elemento muy creativo y original, que va más allá del canon religioso establecido. Si se acepta el origen árabe que propone Georgieva ${ }^{75}$, la mujer que descubre su cara ante el público es una interpretación osada aún para un icono tan tardío.

Sin embargo, la semántica de este gesto de desvelarse puede ser muy distinta, en el caso de tratarse de una interpretación defectuosa, libre, o sincrética si se han

\footnotetext{
Kenderova 2002, 42.

Kenderova 2002, 42.

71 Se data alrededor del año 150; aunque nunca fue incluido entre los evangelios canónicos, recoge leyendas que han sido admitidas como ortodoxas por algunas iglesias cristianas, tales como la natividad milagrosa de María, la localización del nacimiento de Jesús en una cueva o el martirio de Zacarías, padre de Juan el Bautista.

72 Kenderova 2002, 42.

73 [...] Y he aqui que los sacerdotes se reunieron en consejo, y dijeron: «hagamos un velo para el templo del Señor [...]» E introdujeron a las jóvenes en el templo del Señor, y el Gran Sacerdote dijo: «Echad a suertes sobre cuál hilará el oro, el jacinto, el amianto, la seda, el lino fino, la verdadera escarlata y la verdadera púrpura». Y la verdadera escarlata y la verdadera púrpura tocaron a María, que, habiéndolas recibido, volvió a su casa. Y, en este momento, Zacarías quedó mudo, y Samuel lo reemplazó en sus funciones, hasta que recobró la palabra. Y María tomó la escarlata, y empezó a hilarla, González Blanco 2014, 42.

74 Kenderova 2002, 43.

75 Georgieva 2002, 64-65.
} 

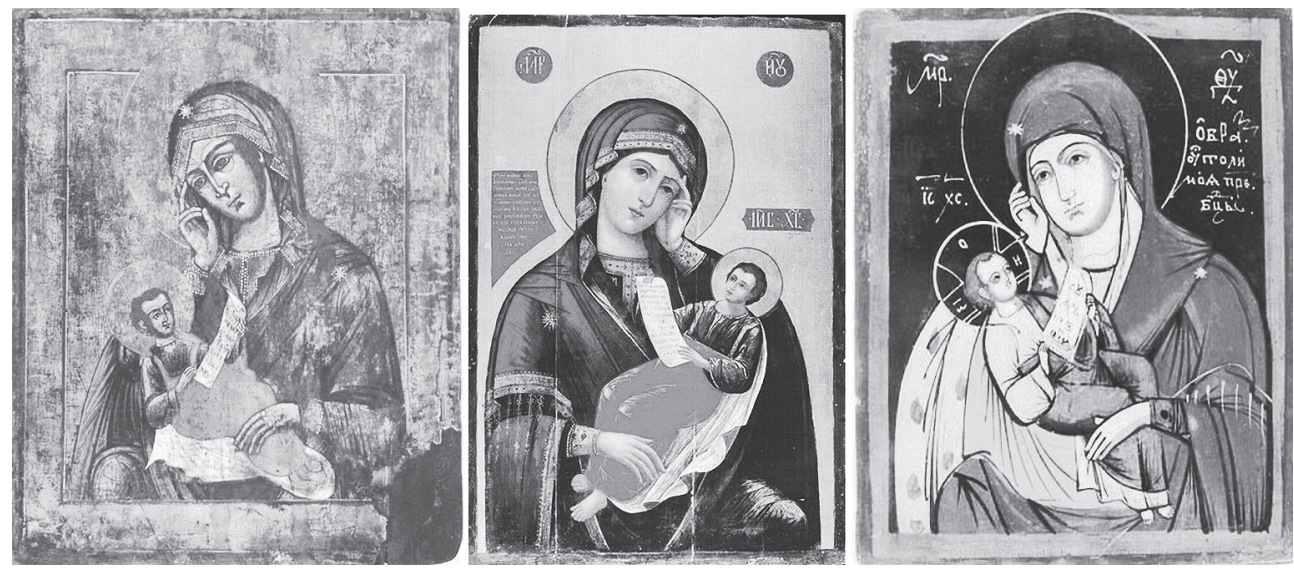

Figura 7. La Virgen con el Niño, iconos rusos ortodoxos de tipo Bogomater Utoli maia pechali, de rus. 'Consuela mi pena'.

tomado como modelos varios prototipos, o bien, de una modificación secundaria. En este sentido me llamó la atención que mientras la Virgen «mantiene» su velo, los dedos de su mano están representados en una posición bien conocida por las primeras imágenes cristianas, imitando las siglas I XC, iniciales griegas que se refieren al nombre del Señor Jesucristo ${ }^{76}$.

En la búsqueda de una analogía con otras imágenes, llegué a la conclusión de que la representación de la Virgen con la mano levantada de ese modo es muy singular y poco frecuente entre los tipos más usados. No obstante, existe una posición iconográfica en la que La Madre de Dios aparece con el brazo doblado por el codo y se toca la sien o la frente con la mano. Se trata de «Богоматерь Утоли моя печали» [Bogomater Utoli moia pechali] la Virgen Consuela mi pena ${ }^{77}$, icono que expresa el sufrimiento de María por ver morir injustamente a su único Hijo en el Gólgota (fig. 7) ${ }^{78}$. La primera imagen de la Virgen de ese tipo data de mediados del siglo XVII y se encontraba en Shkolov, la actual Bielorrusia; por sus milagros se hizo tan famosa que a comienzos del siglo XX se llegaron a editar muchas estampas con esa imagen. Después de la revolución, las huellas del icono se pierden, pero se conservaron algunas copias. Una de estas copias, la más famosa, la llevaron los cosacos a Moscú en 1640. Según la tradición, en tiempos del zar Alexey Mihaylovich, instalada en la iglesia de San Nicolás, esa imagen obró muchos milagros, sobre todo durante la peste de 1771, cuando su veneración se reforzó considerablemente. En 1760 se construyó un altar lateral en consideración a este icono milagroso y se estableció el día 25 de enero ( 7 de febrero) como fiesta para su celebración ${ }^{79}$.

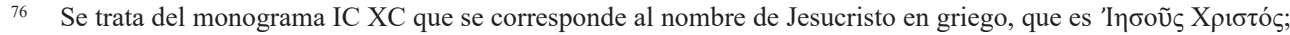
transliterado al alfabeto latino: Iesous Christos; se forma tomando la primera y la última letra de cada palabra, que en el caso no es la $\mathrm{S}$, porque el grafema que se usaba para designar la sigma (S) en el griego bizantino era $\mathrm{C}$ (así como en el alfabeto cirílico actual, el grafema $\mathrm{C}$ tiene valor fonético de $\mathrm{S}$ ).

77 También Calma mis tristezas.

78 El nombre del icono se retoma de la quinta estrofa del Acátisto de la Virgen: «consuela la pena de mi alma».

79 Muchas iglesias fueron consagradas a este icono. 
Se conocen algunas variantes de la composición de la imagen en las que la Santísima Virgen gira a la izquierda o a la derecha. Los dos dedos de su diestra están doblados, formando las iniciales del monograma de Cristo, IC XC, lo que muestra el origen antiguo de la iconografía (y lo que se observa en la imagen de Tatáritsa). Cristo está sentado en las rodillas de Su Madre, o flota libremente sobre su manto, sin el soporte habitual del brazo, indicando una dimensión incorpórea. La cabeza de la Virgen esta inclinada hacia el Niño, pero su mirada está dirigida hacia algo lejano o sobrehumano. Jesucristo mantiene el rollo con las letras:

Juzgad juicio verdadero, $\mathrm{y}$ haced misericordia y piedad cada cual con su hermano: no agraviéis a la viuda, ni al huérfano, ni al extranjero, ni al pobre; ni ninguno piense mal en su corazón contra su hermano (Zac. 7:9-10).

\section{Conclusiones}

En conclusión, por una parte se puede suponer que el problemático gesto del icono de Tatáritsa puede resultar de una interpretación libre del gesto de la Virgen, conocido ya en el famoso icono ruso Consuela mi pena, sin olvidar también la Virgen Odiguitria de Kazán, que probablemente sirvió como modelo principal. Y aunque no disponemos de suficientes argumentos, no es de despreciar que, como se ha dicho, las dos imágenes históricamente están vinculadas justo con los cosacos, entre los que ambas gozaban de veneración especial, y que sus descendientes, perseguidos en Rusia, encontraron refugio en Bulgaria, fundando el pueblo de Tatáritsa (hoy Aydemir), donde fue encontrada dicha imagen. Esos antiguos cosacos, como hemos visto, habían acogido diversidad de etnias, entre ellos tártaros de Don, formando finalmente una comunidad homogénea.

Por otra parte, si no se toma en cuenta el lugar de su hallazgo y devoción, la hipótesis sobre el origen copto del icono se defiende muy bien.

Pero sea su origen egipcio-etíope o bien ruso-cosaco-tártaro, lo importante es que esta imagen cristiana con citas coránicas, es decir, en cierta medida herética, es custodiada en un pueblo famoso por su celo religioso cristiano, lo que nos conduce a la vía del fenómeno del santo de todos ${ }^{80}$, mostrándonos una lógica diferente. Pese a su singularidad, este ejemplo es indicativo del sincretismo cultural y religioso, característico de territorios con poblaciones mixtas tanto en lo étnico como en lo religioso. Por ello, encontrarlo en Bulgaria, proceda de donde proceda, no resulta casual, ya que esta es una tierra sometida a migraciones de poblaciones diversas, que han estado introduciendo innovaciones en sus respectivas tradiciones, dando lugar a semejantes formas de devoción como la observada.

El ambiente sincrético que reunió personajes cristianos y citas coránicas del libro sagrado de los musulmanes, bien ajustadas y nada contradictorias en un universalismo homogéneo, quedo estampado en «una interpretación inusitada» ${ }^{81}$ de la Virgen y el Niño.

80 Sobre este fenómeno, véase el capitulo «el Santo de todos» en Spasova Ilieva 2015, 607-674.

81 Como juego con el título que Teodora Georgieva da a su artículo, 'La Virgen con el Niño- una interpretación inusitada' (en tr. de búlg.). 
Simbólicamente podemos decir que el icono de Tatáritsa, con su peculiaridad, impregnó el estado espiritual, social y religioso de ese ambiente, que a su vez dio pie al nacimiento de tal tipo iconográfico, que formaba parte de la percepción personal del autor, pero también de la capacidad de recepción de los fieles, que sintieron devoción por esta interpretación y la reconocieron cercana a su contexto religioso, no muy lejano del sincretismo que la originó.

\section{Bibliografía}

I. Boteva, «Великден при староверците от село Татарица» [Velíkden pri starovétsite ot sélo Tatáritsa], http://myroads.mobi/10609/velikden-pri-starovertsite-ot-selo-tataritsa/, publ. 7. 04. 2015 [acceso: 24.02. 2017].

T. Georgieva, «Богородица с Младенеца- една необичайна интерпретация» [Bogoróditsa s Mladenétsa- edná neobicháyna interpretátsia]/'La Vierge à l'Enfant: une interprétation inusitée', (en búlg., con tít. búlg. y fr.), Les Saints Slaves dans l'histoire de l'Église Chrétienne, Annuaire de l'Université «St. Kliment Ojridski», Ax. Dzhurova (ed.), Centre de Recherches Slavo-Byzantines «Iván Duychev», Sófia, Ed. «St. Kliment Ojridski» 9211 (2002) 61-65.

Ed. González Blanco (trad. y ed.), «Protoevangelio de Santiago», Evangelios apócrifos,

Barcelona, Linkgua, (2014) 37-50, https://books.google.bg/books?isbn=8498976200 [acceso: 14.08. 2016].

J. Jrisoulas, «El Icono Heleno-bizantino», Lodos ortodoxo, 15 sep. 2014, http://www.logo sortodoxo.com/teologia-ortodoxa/el-icono-heleno-bizantino/ [acceso: 05.08. 2016].

J. Jrisoulas, «Jaris de Dios», Lodos ortodoxo, 20 feb. 2013, http://www.logosortodoxo.com/ teologia-ortodoxa/el-icono-heleno-bizantino/ [acceso: 21.08. 2017].

St. Kenderova, «Исус Христос и Дева Мария, представени в исляма»/Jésus Christ et la Vierge Marie représentés dans l'Islam, (en búlg., con tít. búlg. y fr.), Les Saints Slaves dans l'histoire de l'Église Chrétienne, Annuaire de l'Université de Sofia «St. Kliment Ojridski», Centre de Recherches Slavo-Byzantines «Iván Duychev», A. Dzhurova (ed.), Sófia, Ed. «St. Kliment Ojridski», 9211 (2002) 39-49.

V. O. Kliuchevskiy, Курс Русской Истории [Kurs Rusckoy Istórii] ('Curso de Historia de Rusia') http://pstgu.ru/download/kurs.pdf [acceso: 07.09. 2016].

M. Kort, The Soviet Colosus: History and Aftermath, Armonk, 2001.

O. Yu. Kuts, «Татары на казачьем Дону» [Tatarăy na kazachem Donu] ('Tártaros en el Don de los cosacos'), Исследования по истории средневековой Руси. Сборник Статей, посвященны 80-летию Ю. Г. Алексеева ('Investigaciones sobre la Rusia medieval. Colección de documentos dedicados al $80^{\circ}$ aniversario de U. G. Alekseev'), Moskvá, Sankt-Peterburg, Ed. «Samizdat», (2006) 398-414, http://samlib.ru/k/kuc_oleg_jurxe wich/tatarynadonu2006doc.shtml [acceso: 05.08. 2016].

G. Magner, «Разказачивание в системе массовы репрессий» [Razkazachivaniye v sisteme masavăy represiy] ('Descosaquización en el sistema de represión masiva'), Альтернативы/Alternatives, A. Buzgalin (ed.), Moskvá, 4 (1999), http://www.alternati vy.ru/old/magazine/htm/99_4/istoria.htm [acceso: 13.09. 2016].

Gh. Metalinós, Protopresbítero, «Iglesia Ortodoxa. ¡La Ortodoxia es la única verdad!», Lodos ortodoxo, J. Jrisoulas (trad. gr.), 2014, http://www.logosortodoxo.com/ortodoxia/ [acceso: 14.08. 2016].

Ah. Mohammad Issa, Painting in Islam: Between Prohibition and Aversion, Istanbul, IRCICA, 1996. 
M. Polo, Le Dévissement du Monde: Le livre des merveilles, A. C. Moule y P. Pelliot (eds.), trad. al fr. L. Hambis, intr. y nts. St. Yerasimos, Paris, Ed. F. Maspero, 1982.

E. Ros Leconte, Reflexión sobre el icono sacro bizantino, Barcelona, Balmes, 1984.

E. Sendler, «Светът на цветовете» [Svetăt na tsvetovéte] ('El mundo de los colores'), Spisanie Mirna, P. Sivov (trad. ingl. de la ed. The Icon: Image of the Invisible, Oakwood Publications, 1995), Sófia, Ed. Omofor, 24 (2005) 69, http://www.pravoslavie.bg/Символика/ Светьт-на-цветовете/ [асcеso: 04.08.2016].

V. Spasova Ilieva, «La santidad compartida: la encrucijada del islam y la ortodoxia cristiana en los Balcanes, reflejos en Bulgaria», Tesis doctoral, Facultad de Filología, Universidad Complutense de Madrid, (2015), E-Prints Complutense, http://eprints.ucm.es/39974/1/ T37972.pdf [acceso: 24.02.2017].

V. Spasova Ilieva, «Los kizilbashes y el culto a los santos en Bulgaria: entre el Cristianismo y el Islam de los Balcanes», trabajo de investigación de tercer ciclo para obtener el DEA, Facultad de Filología, Universidad Complutense de Madrid, (2007), inédito.

Sacerdote V. Vladimirskiy, «O состоянии иконописания» ('Respecto al estado de la iconografía'), О церковной живописи [O tserkovnay zhivopisi] ('Respecto a la pintura eclesiástica'), Sankt-Peterburg, Ed. «Obshestvo Vasilia Velikogo», 1998, 100-124.

Чудотворни икони на Пресвета Богородица [Chudotvórni ikóni na Presvetá Bogoróditsa] ('Iconos milagrosos de la Santísima Madre de Dios'), en búlg., trad. de rus. y gr., Ágion Óros, Ed. Slavianobălgarski manastir, «Sv. vmchk. Georgi Zograf», 2006.

Село Айдемир [selo Aydemir], http://www.aidemir.com/index.php?option=com_content\&t ask=view\&id=5\&Itemid=28 [acceso: 24.02 . 2017]. 